\title{
Suma Qamaña as a strategy of power: politicizing the Pluriverse ${ }^{1}$
}

\section{Suma Qamaña como estratégia de poder: politizando o Pluriverso}

DOI: $10.21530 /$ ci.v13n3.2018.818

Ana Carolina Teixeira Delgado 2

\begin{abstract}
The "pluriverse" has recently gained momentum in International Relations among scholars focused on ontological pluralism. Nevertheless, theoretical debates may obscure several political tensions observed in local experience. In this paper, I analyze narratives on Suma Qamaña, which synthesizes Aymara cosmology and is both reproduced and criticized by political actors in Bolivia. I argue that the discourse on Suma Qamaña entails a strategy of power by both Aymara people and the government. The paper is developed in three parts: first, I examine the term`s framing in literature, Suma Qamaña`s risen in Bolivian society and its connection to the reconstruction of Aymara identity. Then, I analyze Suma Qamaña`s insertion into governmental discourse. Finally, I stress power disputes over Suma Qamaña. I suggest that the emphasis attributed by IR academics to its ontological potential without considering this strategic facet might lead them to depoliticize the term, reproducing a similar pattern advanced by other theorists and the government.
\end{abstract}

Keywords: Suma Qamaña; pluriverse; Bolivia.

\section{Resumo}

O "pluriverso" adquiriu recentemente impulso na disciplina de Relações Internacionais entre os acadêmicos preocupados com o pluralismo ontológico. Entretanto, os debates teóricos podem obscurecer diversas tensões políticas observadas no local. Neste artigo, analiso

1 Article based on PhD research sponsored by CNPq.

2 Ana Carolina Teixeira Delgado is an Assistant Professor and Researcher at the Federal University of Latin America Integration (Unila). She holds a PhD from IRI/PUC-Rio and has been investigating social movements for over 10 years. Currently, she vice-coordinates the Theoretical Thematic Area of the Brazilian Association of International Relations (ABRI).

Artigo submetido em 22/06/2018 e aprovado em 11/09/2018. 
as narrativas sobre o Suma Qamaña, expressão que sintetiza a cosmologia Aymara e é reproduzida e criticada pelos atores políticos na Bolívia. Argumento que o discurso sobre o Suma Qamaña encerra uma estratégia de poder exercida tanto pelos aymara quanto pelo governo. Este artigo é desenvolvido em três partes: primeiro, examino o enquadramento do termo na literatura, sua ascensão na sociedade boliviana e conexão com a reconstrução da identidade Aymara. Depois, analiso a inserção do Suma Qamaña no discurso governamental. Finalmente, enfatizo as disputas de poder em torno do Suma Qamaña. Sugiro que a ênfase atribuída pelos acadêmicos ao seu potencial ontológico sem considerer sua face estratégica poderá levá-los a despolitizar o termo, reproduzindo um padrão desenvolvido por outros teóricos e mesmo pelo governo.

Palavras-chave: Suma Qamaña; pluriverso; Bolivia.

The discipline of International Relations (IR) has been increasingly criticized for its exclusionary feature by academics who, although representatives of distinct theoretical perspectives, belong to the same tradition of thought produced mainly in the Anglo-Saxon world (Ashley 1988; Cox 1987; Onuf 1989; Smith, Booth and Zalewski 1996; Tickner 1992; Walker 1993; Wendt 1999). In that sense, its internal diversification would reflect not necessarily an ontological pluralism but the reification of a pretentious universality and, consequently, the marginalization of other knowledge and the modes of life reflected by them. For that reason, many academics either have pointed IR as an American discipline or highlighted its Western, Eurocentric feature (Hoffmann 1977; Biersterker 2009; Ikeda 2010; Jones 2006; Tickner and Blaney 2012; Hobson 2012; Acharya and Buzan 2010; Weaver 1998). Such a move puts into question IR's international or even global vocation once we realize that much published work tends to reproduce concepts and models geopolitically situated. More, such works are based on epistemological and methodological fundaments present among mainstream scholars, and even on modern ontological assets, including much of the criticism directed to the latter.

The advent of postcolonial and indigenous studies has been crucial in denouncing the silencing of difference by the academy, recovering alterity as an important analytical category for the discipline (Beier 2009; Chakrabarty 2000; Grovogui 2006; Inayatullah and Blaney 2004; Lightfoot 2016; Muppiddi 2012; Shaw 2008; Shilliam 2011; Smith 2012). Following this wave of criticism and influenced by social scientists` research on Latin America (Blaser 2010; De la Cadena 2010, 2015; Dussel 2013; Escobar, 2010, 2011, 2012; Latour 2010), the notion of "pluriverse" has recently gained the attention of IR scholars (Conway 
and Singh 2011; Querejazu 2016; Rojas 2015, 2016; Tickner and Blaney 2013, 2017; Youatt 2017; see also International Studies Association 2016 Program). Related to the modes of life of "Non-Western" peoples, the term addresses the complexity of social relations as it advocates the emergence of diverse knowledge and cosmologies which, distinguished from the Modern one, do not place human beings in the center of existence. On the contrary, this "other" perception of "reality" as one composed of "many worlds" itself holds a subversive potential to read critically IR. Nevertheless, the incorporation of this "other" expression by scholars and the sense of novelty attributed to the "pluriverse" might obscure a series of power disputes already present in the local sphere, and considered by Blaser as his concept of "political ontology" refers not only to "a field of study that focuses on the conflicts that ensue as different worlds or ontologies strive to sustain their own existence as they interact and mingle with each other" but also to "the politics involved in the practices that shape a particular world or ontology" (BLASER, 2009, p. 877).

In fact, the relevance of stressing the "political" was pointed by Siba Grovogui in the $56^{\text {th }}$ International Studies Association Meeting as he questioned the "political implications" regarding the emergence of other knowledge and its coexistence with modern institutions already installed in the national and international fields. Inspired by Grovogui`s interpellation, I analyze in this paper narratives on Suma Qamaña, which synthesizes Aymara cosmology and is both reproduced and criticized by political actors in Bolivia. I use the Bolivian case to illustrate: the difficult relationship between the government and indigenous peoples, and among the latter as well; and the consequences that surface once Suma Qamaña is captured by Morales' administration. I argue that discourse on Suma Qamaña entails a strategy of power by both the Aymara people and the government. In this article, I examine the term`s framing in literature, to which follows a brief history of Suma Qamaña`s risen in Bolivian society and its connection to the reconstruction of Aymara identity. Then, I analyze Suma Qamaña`s insertion into governmental discourse. I conclude stressing the power disputes over Suma Qamaña in the Andean country. I suggest that the emphasis attributed by IR academics to its ontological potential without considering this strategic facet might lead them to depoliticize the term and reproduce a similar pattern advanced by other theorists and Morales`administration. 


\section{Suma Qamaña and the reconstruction of Aymara identity}

Translated simply as Living Well (Vivir Bien, in Spanish), Suma Qamaña consists in one of the expressions found in the international academic literature devoted to the emergence of an other logic, proper of the Andean indigenous peoples and opposed to modern rationality. Current work in Social Science points Suma Qamaña as the aymara counterpart of the quechua Sumak Kawsay/Good Living (Buen Vivir). Both are interpreted either as an alternative to development, to capitalism, to coloniality, an example of solidarity economy or even as a solution to the crises of human civilization (Acosta 2009; Dussel 2012; Escobar 2012a; Gudynas 2011; Lander 2010; Quijano 2012 Santos 2010; Walsh 2010). In IR, references are still scarce and sometimes made in relation to the notion of pluriverse, which translates theorists` effort to establish an ontological criticism of the discipline, stressing its Western colonial feature and the need to incorporate contributions from colonized peoples. That is the case of Querejazu (2016), who advocates that Andean cosmovisions and their conceptual tools, such as the ayllu, could foment IR discussion on multiple issues and bring a more inclusive facet to the discipline.

A similar trend is found in Rojas`s publication on the pluriverse. Here, Suma Qamaña is mentioned along with Sumak Kawsay only to express the difficulty concerning translations among different "worlds", following what Viveiros de Castro (1996) pointed as the irreducible quality of the indigenous cosmology to the notions of a rational-modern debate. Thus, the difficulty framing them in terms of single units. Nevertheless, because these other subjectivities, to which Suma Qamaña forms part, are presented as "oriented toward alternatives to colonial logics” (ROJAS, 2016, p. 380), Rojas advocates their potential to decolonize international politics. Earlier, the author had identified Suma Qamaña to practices of decolonization, critical to the modern project of citizenship and its supposed universality. Although the expression is related to the Aymara people, Rojas (2015) also presented it as an equivalent of "Buen Vivir”, extensively pointed by the literature as a translation of quechua Sumak Kawsay. Elsewhere, she framed indigenous knowledge in Bolivia as an example of a "noncapitalist alternative" which, together with its counterparts produced by diverse marginalized cultures in Latin America and abroad, could encourage dialogue between different economic practices. In that sense, indigenous knowledge in the Andean country would present a possibility to decolonize International Political Economy fundaments and, 
as such, to promote "development otherwise", that is, a new form of economic organization sustained in the co-existence of different "rationalities" (ROJAS, 2007, p. 585).

Although Rojas didn`t specifically mention Suma Qamaña nor Living Well, she highlights Aymara descent of president Morales and his role, along with indigenous intellectuals, including "other" proposition in norms and public policies. Querejazu, in turn, grounds her analysis basically on propositions made by several Bolivian indigenous and non-indigenous authors, including some considered the founders of Suma Qamaña. The emphasis put by these IR authors on Andean indigenous knowledge or simply indigenous knowledge in Bolivia, and even Rojas` "noncapitalist alternative”/ “alternative to colonial logics” is quite revealing. Their concern is first and foremost a theoretical one, which privileges ontological difference presented by non-Western colonial worldviews and their prospects for the discipline, leaving aside political disputes between the Bolivian government and indigenous peoples, divergence among indigenous groups over Suma Qamaña/Living Well. Thus, they put in second place strategies employed by those actors. In doing so, they emulate somehow the work of social scientists who focus on Andean indigenous knowledge and its otherness in relation to Modernity, and stress only partially political implications regarding the emergence of this "other" ontology in Bolivian society. More, they miss Suma Qamaña as a strategy of power by both Aymara people and Morales`government.

Apart from the Spanish or English translation, Suma Qamaña and Sumak Kawsay mean "life in plenitude”, referring to a dynamic process since "qamaña” and "kawsay" indicate the relevance of "being" as condition of existence instead of "to be". ${ }^{3}$ In the great tissue that represents life (Pacha), formed by the complementarity of opposed forces (cosmic and telluric), everything is interconnected. ${ }^{4}$ According to this logic, human beings are just an integrative part of a whole, which embodies the material plan, manifested in mineral, vegetable and animal forms, and the supernatural one. Such an understanding relates to the Aymara principle Take kunas jakaskkiwa ("Everything lives”): humans and non-humans (despite of their material composition) emanate energy and comprise the cosmos which, at the

3 Qamaña is translated as “estar siendo” and Kawsay as "ser estando”. See Huanacuni (2010) "Vivir Bien/Buen Vivir. Filosofía, políticas, estrategias y experiencias regionales” and Oviedo (2012) "Qué es el SUMAKAWSAY. Tercera Via: Vitalismo, alternativa al capitalismo y el socialismo”.

4 Pacha, in aymara and quéchua, means life. "Pa" indicates number two, "paya”, and "cha” comes from the word "chama”, which denotes force/energy. Author`s personal notes. 
microlevel, is reflected in the ayllu. ${ }^{5}$ For that reason, existence implies a constant search for balancing, for harmony between the visible and nonvisible worlds, which is expressed in the modes of life of the so-called "ancestral" peoples, such as indigenous ones.

Central to those modes of life is the practice of ceremonies since they establish a connection between the worlds and guide social relations in community as well. In Aymara communities, ceremonies are usually related to the Andean-Amazon calendar, marked by agricultural cycles, and consist in acts of celebration of life, during which rituals, music and dancing are performed. As a fundamental expression of this symbiotic relation between what would otherwise be named as man and nature, ceremonies are not separated, thus, from other activities, such as economic production. This still holds despite the gradual marginalization of rituals in everyday life of those groups, mainly in those whose majority of members migrate to the cities.

Whereas Sumak Kawsay/Good Living is connected by academics to Ecuador, Suma Qamaña/Living Well is related to indigenous experience in Bolivia. In both cases, international literature puts special emphasis on the similarity between those concepts and their understanding of the world, stressing Sumak Kawsay/ Good Living. As a result, academics neglect Bolivian experience, the disputes occurred in the country and related to its colonial past/present, subsuming the Aymara expression to the Quechua one. For IR, in particular, the consequences presented by this move are multiple: as mentioned before, current analysis tend to homogenize knowledge and modes of life enacted in distinct local/national political conditions for the sake of theoretical robustness of their arguments against the discipline's Modern colonial logics and lack of pluralism. In that way, they silence conflicts that surface on a daily basis, which puts their work in sharp contrast with the literature on the pluriverse and political ontology, one of their major references. Although IR scholars stress Modernity's concealment of knowledge and practices of other peoples, often colonized ones, through a series of dichotomous pairs (nature versus culture, civilized versus non-civilized etc.), they miss another important qualitative proposition presented in the literature on the pluriverse.

As Blaser (2010) attentively put, the pluriverse is about different worlds, that is, ontologies that interact and clash with each other, pervaded by power disputes,

5 Personal notes. 
asymmetry and negotiations. If we understand that those disputes occur not only between collective actors that reproduce different knowledge, modes of life, but also among those actors themselves, we have a much more complex picture than the one offered by IR authors, mostly focused on the dichotomy Modern/colonial versus Non-Modern/decolonial/homogenized other. Alternatively, we would have a non-romanticized analysis that contemplates the other in its otherness without obliterating political dimension, an issue also discussed by De la Cadena (2015) as well as postcolonial authors such as Memmi, and Fanon. That point is made clear once we concentrate on the dynamics around Suma Qamaña. In what follows, I stress the role of identity and the strategic incorporation of otherness by indigenous peoples in Bolivian Highland.

Suma Qamaña/Living Well's construction emerges in a context of indigenous and peasantry resistance to neoliberal policies, that lead to the impoverishment of society and affected severely those collective actors. Also, the risen of Suma Qamaña should not be isolated from the formation of an Aymara intelligentsia from the 1970`s on who, after their relative`s migration to the city of La Paz, especially, tried to break the inferior status attributed to the indigenous and get jobs other than housekeeper, artisan. The first quotes regarding Suma Qamaña date back to the beginning of the 2000`s, a period of intense mobilization in Bolivia. In the department of La Paz, the protesters were led by Aymara and Executive Secretary of the Peasant Workers`Union Confederation of Bolivia (Confederación Sindical Única de Trabajadores Campesinos de Bolivia, CSUTCB) Felipe Quispe, who succeeded in isolating the country`s administrative capital for months by blocking the roads. Initially, their demands related to the concentration of land, denouncing the misery experienced by small farmers and indigenous communities besides the strong discrimination towards them. As conflict escalated, their discourse included a critique to corruption, traditional political parties and, in particular, to the racist colonial structure, crystallized in the difference between indigenous groups and White-mestizo elite.

During the road-blocking, indigenous groups constructed a grammar of empowerment, stressing the separation between "self" and "other". As Mamani (2012) states, those were exceptional moments that contributed to the development of a common identification among the protesters, strengthening Aymara identity by using of traditional clothing, whiphala (checked colorful flag that reflects indigenous struggles in Spanish America) and pututu (brass instrument). The 
exercise of ayni, expressed in the mutual help among community members and the idea of reciprocity, and the achievement of consensus among participants represented as well, according to the author, social codes embodied in the ayllu (Andean indigenous community). As mobilization and identity reinvention developed, insurgents began to reproduce a historical demand for territory and autonomy, enacted by aymara people during colonial and republican Bolivia, as shown by Choque (2012) and Thompson (2010) in their analysis on indigenous struggles in the 19 th and 18 th centuries, respectively.

In that way, La Paz insurgency seemed to mark not just the search for liberation, but also the return of an actor in his otherness, whose discourse reproduced some of Fausto Reinaga`s appointments. First academic aymara whose work focused on the relevance of indigenous empowerment for the reconstitution of Kollasuyu and Tawantinsuyu ${ }^{6}$, Reinaga influenced following generations and had some of his propositions incorporated by Quispe as a strategy to incite resistance:

"Since 1563 [...] we've lost the State, and then political power, and then the right to have our own president. [...] What do we want? We want to restore Tawantinsuyu [...] Since Spaniards came [...], we`ve been nothing but cannonball. The truth is that this land (patria) is ours, they are stateless, they have no State.

[...] Let's see: who sweeps the street? We, the Indians. [...] White people are there as architects, engineers, staring down Indians that are working. [...] I've mobilized people with this discourse. I formed myself intellectually in Cuba. When I got here, I wanted to apply the same experienced I had there. People didn`t understand me... Then, I thought: "How can I raise these people? Oh, we should talk about the Incas, Katari, about the Aymara, our life, the ayllu, the community, ayni”. They, then, lifted their neck like a llama. That was the secret..." (DELGADO, 2014. Interview with Felipe Quispe, La Paz, April 2013.?

6 The Inca Empire, or Tawantinsuyu, was subdivided in many administrative regions (suyus). One of those was Kollasuyu, which comprehended the highlands of Peru, Bolivia, as well as Northen Chile and Argentina. Kolla is the one who is original from Kollasuyu.

7 “Desde 1563 [...] habemos perdido el Estado, luego el poder político, y luego tener nuestro próprio presidente. [...] Qué pretendemos hacer nosostros? Nosotros queremos restaurar el Tawantinsuyu [...] Desde que han llegado los españoles [...] hemos sido carne de cañon y nada más. Es verdade que esta pátria es nuestra, ellos son apátridas, no tienen pátria.

[...] A ver: quien varre las calles? Nosotros, los índios. [...] Ser blanco ahí está como arquitecto, enginiero, mirando los índios que están trabajando [...] Yo he levantado la gente con este discurso. Yo me he formado en Cuba. Cuando he llegado acá, queria aplicar lo mismo. La gente no entendia... Entonces, yo de pronto he pensado: "Cómo puedo levantar la gente? Hablaremos de los incas, de Katari, de aymara, nuestra vida, del ayllu, de la comunidad, del ayni” La gente llevanta el cuello como uma llama. Entonces, ahí há estado el secreto...” 
The passage above reflects a dynamic of identitarian redefinition and selfaffirmation, pointed by Mamani as one of the specificities of the indigenous uprising in La Paz, as collective actions enabled and were pervaded by a discourse that separated "them" (White/mestizo) from "us" (indigenous/peasantry). Quispe`s idea was to "indianize" indigenous peoples, recovering their identity and selfesteem and, as a result, preparing them for the "Indian Revolution" defended by Reinaga (2011). Such a revolution would consist not just in the State reform, but in restoring political power using a military and rhetorical strategy, stressing difference. Liberation, thus, would entail a violent and radical process, reflecting Fanon`s concept of decolonization and the author`s perception that the goal of the colonized is to occupy the place of the colonizer, that is, to occupy political institutions, to rule the State (FANON, 2004). Moreover, Quispe`s el ayllu, la comudad, el ayniwords reveal the enduring feature of colonial difference, the connection of the ethno-racial and class problematic, described by Bhabha as the "racialization of inequality" (BHABHA, 2004, xiii), and which is not overcome after formal Independence.

Another point highlighted in the interview, which relates to Fanon`s propositions, is the Manichean vision of the colonial world, the sense for the colonized that the colonizer represents the foreigner that took over indigenous land, updating the category of colonizer, now represented by the White-mestizo elite. Quispe, then, tries to subvert colonial difference, pointing White-mestizo as the "other" and presenting indigenous world as "fundamentally different" (FANON, 2004, p. 6). In that way, essence will be mobilized as a discursive principle capable to foment indigenous empowerment, in what Memmi called the "return of the pendulum": "What remained for the colonized (and in general, for all oppressed people, I would later argue) was simply to accept themselves, since no one else would accept them. [...] There was no other way out” (MEMMI, 2000, p.48). Thus, Memmi, argues

"to affirm one`s difference becomes the condition of self-affirmation, the banner for the individual or collective reappropriation of one`s self. Where, in the first instance, the dominant affirmed their difference over and against those they oppressed, in the last, the oppressed reclaim their differences against the dominant” (MEMMI, 2000, p. 48-49).

Although diverse from Quispe`s approach, self-affirmation is also displayed in narratives on Suma Qamaña/Living Well. In this case, the emphasis put on 
the existence of essentially different worlds (the indigenous`world and Whitemestizo Western one) reflects aymara academics effort to demonstrate Suma Qamaña as a new paradigm for humanity (Huanacuni 2010; Yampara 2001, 2005). Here, colonial difference is framed explicitly in cosmological terms and denotes an abyss between distinct modes of life - Western-modern $v s$. indigenous one:

One is the Western cosmovision, where not only theological theory is privileged but, in it, the protagonist and privileged role of Man over other members of the biotic community as if the world was in his hands and had natural tributes to domesticate, take and pillage territories, resources and peoples - Uraqit yanaka yaqha markanakampi apsuyasa jakaña - that's the logic of capital`s worlding and the role of transnational companies. In this cosmovision, material and spiritual expressions are divorced [...].

Other very distinct is Qamañ-Pacha Andean cosmovision of harmonic coexistence, integral welfare of all members of the biotic community and, as such, a respect for integral life not just human`s [...]. Here the problem of spiritual treatment is part of life. It requires interaction among forces and energies using deities to reach harmony and welfare, even though that's understood as paganism and superstition in the Western space. In the Andean cosmovision, that`s a vital part of life [...]. (YAMPARA, 2005, p. 57, translated by us/our translation) ${ }^{8}$

Interestingly, the discursive devices for self-affirmation mentioned above also seems to reflect what De la Cadena (2015) observes as "cosmopolitics". By denouncing "Western cosmovision" (to use Yampara's words) and its contradictions, indigenous academics find a way to act in Western-Modern world. This is possible because, while stressing colonial difference in cosmological terms, those academics were able to establish a dialogue, a connection to this non-indigenous world so that Suma Qamaña is presented as a "new paradigm for humanity". Thus, while rejecting the nature-humanity divide, as De la Cadena states, this does not prevent

8 Una es la cosmovisón occidental donde no solo se privilegia la teoria teológica, sino en ella, el rol protagónico y privilegiado del hombre sobre los otros seres membros de la comunidad biótica, cuál si el mundo estuviera en sus manos y tenga los atributos naturales de domesticar, coger y saquear territórios, recursos y pueblos Uraqit yanaka yaqha markanakampi apsuyasa jakaña - eso es la lógica de la mundialización del capital y el rol de las transnacionales. En esta cosmovision, están separadas, divorciadas la expression material de las cosas de las expresiones espirituales [...]

Outra muy distinta es la cosmovisión andina Qamañ-Pacha de la convivencialidad armónica de bienestar integral de los seres membros de la comunidade biótica, por tanto respeto a la vida integral y no solo humano [...] Aqui, el problema del tratamento espiritual es parte de la vida. Es más bien, interacionar por médio de las deidades essas fuerzas y energias hacia la armonía y bienestar, si bien eso se entende como paganismo o superchería desde el espacio occidental. En la cosmovisión andina eso es parte vital de la vida [...]. 
indigenous from getting closer and, sometimes, capitalize on it. So, consonant with Fanon's and Memmi's discussion, De la Cadena's argument ratifies the political dimension of indigenous empowerment, to which narratives on Suma Qamaña forms part. Yet, it should be mentioned that aymara intelligentsia's conceptions are not homogeneous, comprising much disagreement over the years.

Yampara`s propositions consisted in a watershed: not only have they influenced the work of other authors, such as Javier Medina (2006) and Josef Estermann (2012), but also fomented academic debate. Such a debate is marked either by a critique toward essentialism, what would be a mythification of indigenous peoples, either by a conceptual problem regarding Suma Qamaña (Choque 2013; Kallisapa 2013; Macusaya Cruz 2013; Portugal Mollinedo 2013; Spedding 2010; Stefanoni 2012; Untoja 2012). In any case, those critique reflect the echo encountered by the expression among Bolivian intellectuals (indigenous and non-indigenous) and prompted them in developing studies on the issue to improve definition or even just to mark ideological positions and stress the political facet of indigenous struggles. So, at first, Suma Qamaña discourse was marked by the Highland insurgency against Bolivian State. Passed a decade from those events, such a discourse still resonates in a society characterized in these late years by the "whitening" of many indigenous that migrated to the cities and their descendants. ${ }^{9}$

Certainly, a closer view of Bolivian society reveals a demystification of the indigenous as merely a community member or a minor worker: indigenous groups are much more heterogeneous as collective actors and englobe an emerging class of Aymara and Quechua business men, also defined by Untoja (2012a) as "Kolla hegemony", small farmers and great landowners. The positions assumed by these actors reflect and reproduce power disputes in the national scene, which the government`s manipulation of Suma Qamaña takes part of. In the next section, I analyze Morales`s administration discourse on this Other knowledge and its projection in the international community.

9 This is suggested by Benjo Alconz, member of the National Council of Ayllus and Markas of Qullasuyu (Conamaq), in his intervention during the Foro Estado Plurinacional VS. Estado Republicano (Plurinational State VS Republican State Foro), occurred on October 2nd, 2012. La Paz, Bolivia. Author`s notes. 


\section{Para Vivir Bien: the governmental discourse and its insertion in the international sphere}

Para Vivir Bien (In order to Live Well) consists in the main slogan adopted by Morales' administration and reproduced constantly by diverse State institutions in order to legitimize public policies. ${ }^{10}$ The overwhelming reproduction of Suma Qamaña's Spanish translation by the government made some critics point to a process of political emptiness of the term that would serve to sustain domination through the praise and visibility of the indigenous subject in the official discourse (Mamani 2007). In fact, as an expression capable of being applied to distinct issues, Vivir Bien (Living Well) removes the political content of indigenous resistance as well as the cosmological facet regarding Suma Qamaña, despite the former`s identification as an "indigenous proposition". In that way, the appropriation of otherness in governmental discourse through the incorporation of indigenous ceremonies in the State protocol, the creation of norms, or even the organization of annual meetings with indigenous and peasant leaders would function first and foremost as a device to get their support and keep political alliance.

As those meetings lost gradually their co-ruling feature and assumed a consultative status, and as the Executive started to criminalize indigenous leaders who considered extractivist policies contrary to their self-determination and modes of life, the government's modus operandi became manifest as one of including otherness narrowly. The goal was to create a favorable scenario to governand guarantee the new political elite`s permanence in State institutions (DELGADO, 2014). The absorption of Suma Qamaña as a rhetorical device, which excludes the incorporation and implementation of the logic underlying the expression, is observed in Bolivian Constitution as well as in the National Development Plan Bolivia Digna, Soberana, Productiva y Democrática Para Vivir Bien: Lineamientos Estratégicos 2006-2011 (Dignified, Sovereign, Productive and Democratic Bolivia In Order to Live Well: Strategic Lineament 2006-2011) (BOLIVIA, 2007). In the first instance, Living Well and some of the characteristic attributed to the term complementarity, harmony, balancing - are linked either to moral values, either to economic and political matters that should be assured by the State. Except for article 8, Suma Qamaña is replaced in the document by "Living Well" or "in order to Live Well", the latter indicating not just a sense of purpose but also a

10 Some of those policies are found in Viceministerio de Tierras: Memoria 2012, Agenda Presidencial 2012, and the National Tax Service`s website. 
self-explanatory tone: its use as the ethos of Plurinational Bolivia would justify in and of itself the duties and role of the State as regulator of activities in general and promoter of development despite the normative advocates mechanisms of participatory democracy (see, for example, articles 241, 241 and 316).

"Otherness" is, then, stressed as a subterfuge to promote political centralization in the hands of Morales` government as representative of the State. This governmental tactic and the issues highlighted above appear more clearly concerning the National Development Plan (NDP). The normative, which evokes Living Well along with development, economic productivity and Bolivian sovereignty, reflects what would seem at first a misconception regarding Suma Qamaña, as affirmed by one of the main proponents of the term, foreign minister Choquehuanca: "Maybe we are still using Western concepts. Instead of speaking of a National Development Plan, we should speak of a National Plan about Returning to Balancing, or a National Plan of Life, because development is related to living better, not to Living Well" (CHOQUEHUANCA, 2010, p. 33). But a closer look uncovers the discursive strategy employed by the government in which Living Well stands as an extension of development. The plan`s importance concerns not just its content but the display of an academic grammar, involving a debate on Living Well and its crucial feature to the refunding of Bolivian State.

In that sense, Living Well is classified as the knowledge "characteristic of original and indigenous culture of Bolivia", a "cosmocentric vision that overcomes traditional ethnocentric concepts on development" that reflects "the community`s intercultural coexistence with the other without power asymmetry", "different from Western "living better"” (BOLIVIA, 2007, p. 8). The expression is, thus, understood as the inverse of development whose absorption in State Project would reflect indigenous demand of decolonization. Nevertheless, Suma Qamaña`s incorporation corresponds to the exaltation of difference and political emptiness pattern observed before: once transformed into Living Well, the term is adjusted to State parameters. Its resignification endows official discourse with a new face although, in its structure, the content remains unaltered as suggested by the employment of terms such as "new proposal of development", "new pattern of development", "alternative paradigm to development". Interestingly, the latter reveals the capture of the world "paradigm", pointed by some indigenous academics, along with "alternative to development", a notion widely rejected by Aymara proponents. This suggests a strategic inclusion of Suma Qamaña`s grammar into State`s Living Well discourse: 
Living Well is the demand for development's humanization [...] Living Well is the access to the enjoyment of material resources and of effective, subjective, intellectual and spiritual fulfillment, in balancing with nature and in community with human beings. [...] The linear and sequential concept of progress is insufficient to comprise the new proposal of development because it requires an integral, holistic, radical and accumulative understanding capable of including non-homogenous situations [...]. It unites practices and knowledge from different social actors [...] (BOLIVIA, 2007, p. 9) ${ }^{11}$

The new policy proposes the concept of "development pattern" in opposition to "development model" because it does not search nor utilizes a proved and validated prototype as it seeks to build a new development pattern as a replacement for primary-export model (BOLIVIA, 2007, p. 12)12

Through the manipulation of those terms, State`s discourse provides a critique towards development as an ethnocentric understanding of the world, that reproduces power asymmetry and silences other forms of knowledge. In that sense, it seeks to transpose to the NDP the tension expressed in Suma Qamaña literature between two opposite worlds: indigenous and Western ones. Moreover, its sophisticated grammar establishes a nexus with the propositions of some decolonial authors, as observed in the use of "intercultural coexistence" or the idea that "interculturality is the driving force" of the new development s pattern (BOLIVIA, 2007, p. 13). Besides “interculturality”, other expressions are widely found along the Plan and in decolonial literature as well as "decolonization”, "coloniality”, “colonialism” (Quijano 2005; Walsh, García Linera and Mignolo 2006). Nevertheless, as one proceeds with the document's reading, the emphasis on the empowerment of historically marginalized actors gives way gradually to the prominence of the State as a "transforming force of change" (NDP, 2007, p. 15), whose capacity of guaranteeing the necessary shifts in Bolivian society is linked to the State's return as the promoter of development.

The centralization of power by the State is justified as a condition for recovering Bolivian natural resources, which plays a crucial role in the redistribution of

11 “El Vivir Bien es la demanda de humanización del desarrollo [...] el Vivir Bien es el acceso y disfrute de los bienes materiales y de la realización efectiva, subjetiva, intelectual y espiritual, en armonía con la naturaleza y en comunidad con los seres humanos. [...] La concepción lineal y secuencial de progreso es insuficiente para comprender la nueva propuesta de desarrollo porque requiere de una comprensión integral, holística, radial y acumulativa, capaz de abarcar situaciones no homogéneas [...]. Asimismo une diversas prácticas y conocimientos provenientes de actores sociales diferentes [...]”

12 "La nueva política propone el concepto de "patrón de desarrollo" en oposición al "modelo de desarrollo" porque no sigue ni utiliza un prototipo probado y validado, sino que plantea construir un nuevo patrón de desarrollo en sustitución del primario exportador” 
wealth, and the exercise of sovereignty in midst Morales`s government decision to nationalize hydrocarbons and transnational companies: "Strategic sectors are composed of hydrocarbons, mining, electricity and environmental resources, that protect nationality because they comprise natural resources, regained and recognized as State property" (BOLIVIA, 2007, p. 98). Such sectors would demand a high investment which "explains the necessity of having the State as the protagonist of development by creating or refounding State companies that promote development of these sectors, maximize surplus[...] in a context of balancing with environment" (BOLIVIA, 2007, p. 133-134). Part of this scenario is the industrialization of natural resources, which has received the administration`s attention, as suggested by the advance of gas` processing, the settlement of an industry of urea in partnership with Samsung etc.

Those examples have no connection with Suma Qamaña propositions; on the contrary, they relate to a development Project sustained in the following pillars: State interventionism, reduction of poverty through wealth redistribution, industrialization and economic growth. ${ }^{13}$ Those pillars are pointed by several authors as the characteristics of developmentalist governments in 21st century Latin America and their focus on the extraction and export of natural resources (see Boschi and Gaitán 2009; Gudynas 2009; Svampa 2013; Vidal 2008). In that sense, the NDP would fit the extractivist regional agenda, which completely shocks with indigenous rights, as showed in Isiboro Sécure National Park and Indigenous Territory`s case and the criminalization of indigenous leaders who opposed governmental policies (DELGADO, 2017).

Regarding national sovereignty, the issue figures as a principle to be achieved through State`s empowerment to guarantee development, national unity and a new political pact, despite other types of sovereignty are mentioned (food sovereignty, sanitary sovereignty, indigenous land`s sovereignty). So, on the one hand, the document attests popular participation based on State decentralization and Living Well. On the other, the Plan promotes power recentralization via policies of nationalization, industrialization and the provision of public goods, making the State the promoter par excellence of change in Bolivian society. In this process, the focus on natural resources control and the incorporation of Suma Qamaña/

13 Those pillars are observed not just in official documents but also in diverse news. See Agenda Patriótica 2025, Vásquez (2013) and Agencia Boliviana de Información (2013, 2013a). 
Living Well as the pillar for a "new type of development" function as a device to accomplish a national Project and, simultaneously, to express Bolivian State selfimage, its uniqueness in the international sphere. This confirms Inayatullah and Blaney`s (1995) observation on State sovereignty realization and its connection to wealth access, which puts difficulty for Third World States due to inequality that marks global division of labor. Because states need economic means to exercise their sovereignty, understood by the authors not just as independence but also as the expression of a state's exceptionality in international community, the property of natural resources for Bolivia would consist in a condition for the government to accomplish its unique national Project and, consequently, to realize its selfimage abroad, as discussed below.

Suma Qamaña`s discursive instrumentalization as a source of legitimacy and exceptionality in international society found in foreign minister Choquehuanca a relevant broker, who mediated the contact between the former and the national sphere. ${ }^{14}$ Once absorbed in presidential discourse through the articulation with Bolivian Foreign Ministry, Living Well is catapulted to international fora, projecting simultaneously the country, Morales` administration as an "indigenous government" and the President himself. Besides the minister`s speeches and texts prepared for courses abroad, statements such as "[...] Bolivia begins a strategy that aims to achieve the reconstruction of Living Well and save Mother Earth" (CHOQUEHUANCA, 2010, p.) ratify the points highlighted before:

[...] Bolivia consists in a Messenger for Peace and a Guardian of Life for the entire planet. [...]

The profound change and transformation we are achieving are not just for us, they are proposals and alternative for the world, humanity and the planet. They are light to other peoples that struggle to change their history since there is no other Project in this planet that represents other choice and considers the global level.

If the challenge was big, now the responsibility and challenge are much bigger, now hope is shared by the whole humanity from each corn of the planet, because environmental, financial, political and social crisis we ve been facing in our territory affect global level and comprise the planet [..]

14 According to the literature on social movements, a broker stands as an actor (a person or even an organization) that connects social spaces previously isolated or, in this case, we might think of two different worlds. See Tarrow and McAdam (2005). 
In this context, facing the threat of global crisis, our brother president releases to the world Ten Mandaments in order to save the planet, humanity and life (CHOQUEHUANCA 2010a, 72) ${ }^{15}$

The quotations demonstrate the government`s initiative to project Bolivia, crediting the country`s relevance for the planet to its process of decolonization which, in turn, is linked to Living Well as the bedrock of an exceptional national Project expressed in the Constitution, economic policies and reforms in general. Suma Qamaña`s definition as an alternative for humanity is, thus, absorbed and transposed to the Nation-State as the official representative of such proposal in the international arena. Those observations are also illustrated by the President, during his speech in the Climate Change Meeting, held in Copenhagen. For him, the event presented for Bolivia the chance to "keep our strategy towards Living Well`s reconstruction and the defense of Mother Earth, to advance Ten Mandaments propositions for saving the planet [...], to take our responsibility in maintaining Balancing with Nature” (MORALES, 2010, p. 27).

Suma Qamaña`s transformation into Living Well involves also an academic framing which, reproducing the strategy adopted in the NDP, reflects the administration`s effort to sustain legitimacy among its intellectual allies from abroad by applying their conceptual tools and, in parallel, advance the construction of an exceptionalism. Thus, the idea of creating a "new socialism” or a "communitarian socialism" to improve "21st century Socialism”, stated in official documents, relates not just to the Bolivarian model employed by Chaves` government. Indeed, the expressions unveil a closer connection with Santos`s “Good Living Socialism”, understood as a "mix of knowledge, ancestral knowledge with modern, Eurocentric, progressist one” (SANTOS, 2010, p. 7). The words of president Evo Morales and vice president Álvaro García, pronounced during VIII Congress of Movimiento al Socialismo (governmental political party), made clear this approach. While the

15 [...] Bolivia se constituye em um Mensajero de la Paz y Guardián de la Vida para todo el planeta. [...] Los câmbios y transformaciones profundas que estamos realizando no son solo para nosotros, son propuestas y alternativas para el mundo, para la humanidade y el planeta. Son luces para los otros pueblos que luchan para cambiar sus historias, ya que no existe en este momento, en el planeta, outro proyecto que represente alternativas que toman em cuenta el nivel global.

Sí antes el desafio era grande, ahora la responsabilidade y los desafios son mucho mayores, ahora la esperanza es compartida por la humanidade entera y de todo el planeta, porque las crisis ambientales, financeiras, política y social, que estamos enfrentando em nuestro território, afecya a nível global y abarca el conjunto del planeta $[\ldots]$

Em esse contexto, ante la amenaza de las crisis globales, nuestro Hermano Presidente lanza al mundo los Diez Mnadamentos para salvar al planeta, a la humanidad y la vida. 
former claimed that this new socialism was grounded on Living Well, going beyond class conflict, García explained: "these are the sources of our socialism: on the one hand, the working class, contemporary science and technology and, on the other, communitarism [...]; the sum of worker`s world and communitarian world [...] are the sources of Communitarian Socialism" (quoted in Villanueva 2012). ${ }^{16}$ Hence, the quotations above disclose Suma Qamaña/Living Well`s framing so it could provide academic support and, at the same time, fit the cosmology into slogans and governmental policies. Here, what is at stake is not the implementation of Living Well in accordance with indigenous intellectuals 'proposals, which are presented as radically distinct from the Western world and its capitalist and socialist models. On the contrary, what is at stake is the instrumentalization of Suma Qamaña, transforming the expression into an authentic proposal of socialism under Morales`administration, different from other socialist experiences developed around the globe. Because of its supposed uniqueness, Communitarian Socialism would function not just as an appealing construct to the academic field but also as a source of power to its advocates, that is, governmental authorities that would detain what Inayatullah (200 8) names as "exclusive knowledge". Related to civilizatory and evangelist policies of colonization, as well as to international donation to Third World countries, this expression indicates the superiority of one group based on their singular knowledge about the world, which would endow them with legitimacy and authority over the "other".

In the Bolivian case, Communitarian Socialism works to project the State and the government abroad by capturing the reclaim of exceptionality made by former proponents of Suma Qamaña and transforming it into something else. In parallel, the absorption of its conceptual tools also functions as a strategy that seeks to gain recognition from indigenous and peasants organizations, which form the major support base of Morales' administration, despite the opposition of many indigenous and non-indigenous intellectuals. Thus, while Suma Qamaña instrumentalization might look at first as an opportunity for indigenous movements to transpose it internationally, giving resonance to their mobilization, this projection seems delusional once one realizes that such a process entails the concept`s inclusion in policies that put the sovereign State as the protagonist of political game. Through such an inclusion, Suma Qamaña`s proposals are adjusted by the official discourse, which reproduces the maintenance of exclusionary structures under a supposedly indigenous government.

16 For a previous version regarding “communitarian socialism”, see Morales (2010a). 


\section{Conclusion}

In this article, I've argued that Suma Qamaña/Living Well entails a strategy of power by both Aymara people and the government. Initially attributed to an Aymara intelligentsia, such a discourse worked to reinforce difference, giving it a positive facet, and promote indigenous self-affirmation. Considering the context in which it emerged, Suma Qamaña cannot be detached from the mobilizations developed in the Bolivian Highland nor from the restructure of the ayllu. In that sense, it played a crucial role in the recovery of identity and the promotion of awareness among indigenous peoples, especially Aymara, an issue pointed by Cesaire (2000) as relevant for the liberation of the colonized. Nevertheless, Suma Qamaña/Living Well`s construction is also linked to conflicts of power in the discursive field. On the one hand, it evokes criticism by many Bolivian intellectuals, some of them Aymara. On the other, its incorporation by international academics works in diverse ways: be it through the preponderance of Sumak Kawsay/Good Living, the emphasis attributed to it as synonym of "Andean indigenous thought" or even as an alternative to development, to capitalism and to colonial logic. In any case, Suma Qamaña is transformed by theorists into expressions that tend to confirm their theoretical hypothesis, leaving aside political disputes that take place in the local dimension.

Considering IR scholars, they not just reproduce previous Social Science literature on the issue but also reinforce the tendency mentioned above as their focus is first and foremost a theoretical one. The concern with the ontological difference presented by non-Western colonial worldviews and their prospects for the discipline has as a result the depolitization of Suma Qamaña. In this case, they put in second place divergence over the Aymara cosmology, which involve indigenous and non-indigenous intellectuals. Because such divergence reflects not just an effort to provide conceptual accuracy, but also the growing tension between the government and indigenous movements that lead to the fragmentation of the latter, IR theorists miss the strategies employed by those actors in the Bolivian political game as well. In doing so, they mention only partially political implications regarding the emergence of this "other" ontology in Bolivian society, stressing the friction between Suma Qamaña and Modern logics but not necessarily the continues process of domination and resistance that crosses those disputes, nourishes them, and puts into check the progressive, essentialist and delusional 
character regarding decolonization and indigenous movements in Bolivia.

As a result, IR authors tend to promote a romanticized critique vision of Modern/rational versus Non-Modern logics, the latter represented by a homogenized knowledge/mode of life. And because homogenization and essentialization remove memories pervaded by struggles and stories of the other, as pointed out by Barthes (2002), they depoliticize the colonized. Thus, in the discipline's literature theoretical issues take precedence over empirical research, and the political component of Suma Qamaña, as developed in the local dimension and projected to the international, is underestimated. In doing so, IR authors reproduce and reinforce a similar pattern of depolitization advanced by Social Scientists.

Suma Qamaña`s depolitization is prompted by Morales government, although in a distinct manner when compared to academic literature. In that case, the Aymara concept is incorporated by the ruling elite through the exaltation of otherness whilst its cosmological content is not followed by political leaders in public policies. Converted into Living Well, Suma Qamaña is then applied as a useful slogan in official propaganda: as an expression of what is essentially different in Bolivia, Living Well serves to legitimize the administration and, in parallel, project Bolivia and its government, as well as its indigenous president. Thus, as an organizing principle of discourse, Suma Qamaña is immersed in political disputes that develop in the local sphere and inform the international, which in turn also impact the local, creating a dynamic process. Because conflicts of power and the strategies employed by the actors involved are not considered by international literature, because there is gap between theoretical and empirical research, political implications are only partially considered and Suma Qamaña becomes politically empty in its content. Finally, it should be highlighted that, once Suma Qamaña is transformed into expressions that fulfill theorists' hypothesis and their anxiety for change, IR scholars also contribute to the creation of slogans, which puts into jeopardy their own goal for decolonization.

\section{Referencies}

Agencia Boliviana de Información. "Ministro Arce asegura que Bolivia redujo en 60 veces la brecha entre ricos y pobres.” La Razón, 14 enero 2013. Disponível em: < http:// www.la-razon.com/index.php?_url = /economia/Ministro-Arce-asegura-Boliviapobres_0_1779422094.html > . 
a. "Ban Ki-moon destaca crecimiento económico de Bolivia y liderazgo mundial de Morales.” La Razón, 25 Septiembre 2013. Disponível em: < http://www.la-razon. com/economia/Ban-crecimiento-Bolivia-liderazgo-Morales_0_1913208712.html > .

ACHARYA, Amitav; BARRY Buzan (Eds.). Non-Western International Relations Theory. Perspectives on and beyond Asia. London: Routledge, 2010.

ACOSTA, Alberto. La maldición de la abundancia. Quito: Ediciones Abya-Yala, 2009.

ALCONZ, Benjo. Intervention during “Foro Estado Plurinacional VS. Estado Republicano”. La Paz, October 2, 2012. Personal Notes.

ASHLEY, Richard. "Untying the Sovereign State: a Double Reading of the Anarchy Problematique." Millennium: Journal of International Studies, 17 (2) 1998: 227-262.

BARTHES, Roland. Mitologias. São Paulo: Editora Difel, 2002.

BEIER, J. Marshall. International Relations in Uncommon Places: Indigeneity,Cosmology, and the Limits of International Theory. New York: Palgrave MacMillan, 2009

BHABHA, Hommi. “Framing Fanon”. In: FANON, Franz. The Wretched of the Earth. New York: Grove Press, 2004.

BIERSTEKER, Thomas J. “The Parochialism of Hegemony: Challenges for 'American’ International Relations.” In TICKNER, Arlene B. Tickner; WEAVER, Ole (Eds.). International Relations Scholarship Around the World. London: Routledge, 2009: 308-327.

BLASER, Mario. “Political Ontology: Cultural Studies without 'cultures'?” Cultural Studies, 23 (5) 2009, p.873-896.

Storytelling Globalization from the Chaco and Beyond. Durham: Duke University Press, 2010.

BOLIVIA. Plan Nacional de Desarrollo. Bolivia Digna, Soberana, Productiva y Democrática para Vivir Bien - Lineamientos Estratégicos 2006-2011. La Paz: Ministerio de Planificación del Desarrollo - Gaceta Oficial de Bolivia, 2007.

. “El Presidente en Acción...”, in: Agenda Presidencial, Año 1, No. 1. La Paz: Ministerio de Comunicación - Gaceta Oficial de Bolivia, 2012.

. Memória. Sembrando esfuerzos para vivir bien. La Paz: Viceministerio de Tierras

- Gaceta Oficial de Bolivia, 2012a.

Agenda Patriótica 2025. 13 Pilares de la Bolivia Digna y Soberana. La Paz: Gaceta Oficial de Bolivia, 2013.

BOSCHI, Renato; GAITÁN, Flavio. "Politics and Development: Lessons from Latin America.” Brazilian Political Science Review 3 (2) 2009, p. 11-29.

CÉSAIRE, Aime. Discourse on Colonialism. New York: Monthly Review Press, 2000.

CHAKRABARTY, Dipesh. Provincializing Europe. Princeton: Princeton University Press, 2000.

CHOQUE, Roberto. Historia de una lucha desigual. Los contenidos ideológicos y políticos de las rebeliones indígenas de la Pre y la Post Revolución Nacional. La Paz: Andrés Bello, 2012. 
Interview [March, 2013]. Interviewer: Ana Carolina Teixeira Delgado. La Paz. 2 archives (120 $\mathrm{min})$.

CHOQUEHUANCA, David. "Es fundamental da construcción entre todos del Plan Nacional de la Vida." In: BOLIVIA. Vivir Bien: Mensajes y documentos sobre el Vivir Bien 19952010. Serie Diplomacia por la Vida, Vol. 3, p.30-42. La Paz, Ministerio De Relaciones Exteriores: Gaceta Oficial de Bolivia, 2010.

. “Los Guerreros del Arco Iris.” In: BOLIVIA. Vivir Bien: Mensajes y documentos sobre el Vivir Bien 1995-2010. Serie Diplomacia por la Vida, Vol. 3, p. 68-74. La Paz, Ministerio De Relaciones Exteriores: Gaceta Oficial de Bolivia, 2010a.

CONWAY, Janet; SING,Jakeet. "Radical Democracy in Global Perspective: notes from the pluriverse.” Third World Quarterly 32 (4) 2011, p.689-706.

COX, Robert. Production, Power and World Order: Social Forces in the Making of History. New York: Columbia University Press, 1987.

DE LA CADENA, Marisol. “Indigenous Cosmopolitics in the Andes: Conceptual Reflections beyond "Politics.” Cultural Anthropology 25(2), 2010, p.334-370.

. Earth Beings: Ecologies of Practice across Andean Worlds. Durham: Duke University Press, 2015.

DELGADO, Ana Carolina Teixeira. Guerreiros do Arco-Íris: os caminhos e descaminhos da descolonização na Bolívia no início do século XXI. Tese (Doutorado em Relações Internacionais). Instituto de Relações Internacionais - Pontifícia Universidade Católica do Rio de Janeiro. Rio de Janeiro, 2014.

. “The TIPNIS Conflict in Bolivia”. Contexto Internacional, vol. 39(2) May/Aug 2017, p. 373-391.

DUSSEL, Enrique. Lecture during Primer Encuentro del Buen Vivir, March 2012. http://memorias-encuentrodelbuenvivir.blogspot.mx/2013/10/blog-post_3642.html . “Agenda for a South-South Philosophical Dialogue." Human Architecture: Journal of the Sociology of Self-Knowledge 11(1) 2013, p.3-18.

ESCOBAR, Arturo. "Latin America at a Crossroads.” Cultural Studies 24 (1) 2010, p.1-65. "Sustainability: Design for the pluriverse.” Development 54(2) 2011, p.137- 140. “Más allá del desarrollo : postdesarrollo y transiciones hacia el pluriverso.” Revista de Antropologia Social 21, 2012, p.23-62.

. Una minga para el postdesarrollo: lugar, medio ambiente y movimientos sociales en las transformaciones globales. Bogotá D.C.: Ediciones desde abajo, 2012a.

ESTERMANN, J. “Cris civilizatoria y Vivir Bien. Una crítica fílosófica del modelo capitalista desde el allin kawsay/suma qamaña andino." Polis, Revista de la Universidad Bolivariana 11 (33) 2012, p.149-174.

FANON, Franz. The Wretched of the Earth. New York: Grove Press, 2004. 
GROVOGUI, Siba. Beyond Eurocentrism and Anarchy. Memories of International order and Institutions. New York: Palgrave MacMillan, 2006.

GUDYNAS, Eduardo. "Diez tesis urgentes sobre el nuevo extractivismo. Contextos y demandas bajo el progresismo sudamericano actual.” In GUDYNAS, Eduardo et al (Eds.). Extractivismo, política y sociedad Quito: CAAP (Centro Andino de Acción Popular) y CLAES (Centro Latino Americano de Ecología Social), 2009, p. 187-225. . "Buen vivir: Germinando alternativas al desarrollo.” América Latina en movimiento, año XXXV, segunda época, 2011.

HOBSON, John M. The Eurocentric Conception of World Politics: Western International Theory, 1760-2010. Cambridge: Cambridge University Press, 2012.

HOFFMANN, Stanley. “An American Social Science: International Relations.” Daedalus, Vol. 106, No. 3, Discoveries and Interpretations: Studies in Contemporary

Scholarship, Volume I (Summer, 1977), p.41-60

HUANACUNI, Fernando. Buen Vivir/Vivir Bien Filosofía, Políticas, Estrategias Y Experiencias Regionales Andinas. Lima: Coordinadora Andina de Organizaciones Indígenas (CAOI), 2010.

IKEDA, Josuke. “The Post-Western Turn in International Thoery and the English School.” Ritsumeikan Annual Review of International Studies 9, 2010, p.29-44.

INAYATULLAH, Naeem. "Why do some people think they know what is good for others?" In: EDKIN, Jenny; ZEHFUSS, Maja (Eds). Global Politics: A New Introduction. New York: Routledge, 2008, p.344-69.

INAYATULLAH, Naeem; BLANEY, David. “Realizing Sovereignty.” Review of International Studies 21 (1), 1995, p. 3-20. . International Relations and the Problem of Difference. New York: Routledge, 2004.

International Studies Association. 2016. “ISA 2016 Program”. < http://www.isanet.org/ Conferences/Atlanta-2016/Program > .

JONES, Branwen Gruffydd (Ed). Decolonizing International Relations. Lanham, MD: Rowman and Littlefield, 2006.

KALLISAPA, Illapa. La Paz, Musef, 08/05/2013. 1 arquivo mp3 (130 min).

LANDER, Edgardo. "Estamos viviendo una profunda crisis civilizatoria.” In: América Latina en Movimiento 452, 2010, p. 1-3.

LATOUR, Bruno. "An Attempt at a "Compositionist Manifesto"” New Literary History 41, 2010, p. 471-490

LIGHTFOOT, Sheryl. Global Indigenous Politics: a Subtle Revolution. New York: Routledge, 2016.

MACUSAYA, Carlos. "La Idea de los abuelos." Soundcloud, December 28th, 2013. $<$ https://soundcloud.com/alberto-del-monte-03/la-idea-de-los-abuelos-carlosmacusaya-cruz-minka-28 > . 
MAMANI RAMÍREZ, Pablo. "Evo Morales entre revolución india o contra revolución india.” Willka 1 (1), 2007, p. 9-49.

- Wiphalas y Fusiles. Poder comunal y el levantamiento aymara de AchakachiOmasuyus (2000-2001). La Paz: Flacso, 2012.

MEDINA, Javier. Suma Qamaña. Por una convivialidad postindustrial. La Paz: Garza Azul Editores, 2006.

MEMMI, Albert. Racism. Minneapolis: University of Minnesota Press, 2000.

MORALES AYMA, Evo. "Referéndum Mundial y Conferencia Mundial de los Pueblos sobre el cambio climatic para elegir la Cultura de la Vida o la Cultura de la Muerte”. In: BOLIVIA.. Vivir Bien: Mensajes y documentos sobre el Vivir Bien 1995-2010. Serie Diplomacia por la Vida, Vol. 3, 2010, p.27-29. La Paz: Ministerio de Relaciones Exteriores - Gaceta Oficial de Bolivia, 2010.

. "Los Diez Mandamientos para salvar al planeta, a la humanidad y a la vida." In: BOLIVIA. Vivir Bien: Mensajes y documentos sobre el Vivir Bien 1995-2010. Serie Diplomacia por la Vida, Vol. 3, 2010, p.18-24. La Paz: Ministerio de Relaciones Exteriores - Gaceta Oficial de Bolivia, 2010a.

MUPPIDI, Himadeep. The Colonial Signs of International Relations. United Kingdom: C Hurst \& Co Publishers Ltd, 2012.

ONUF, Nicholas G. World of Our Making: Rules and Rule in Social Theory and International Relations. Columbia, SC: University of South Carolina Press, 1989.

OVIEDO FREIRE, Attawalpa. M. Qué es el SUMAKAWSAY. Tercera Via: Vitalismo, alternativa al capitalismo y el socialismo. La Paz: Garza Azul Editores, 2012.

PORTUGAL MOLLINEDO, Pedro. “Desarrollo, progreso y cosmovisión: mitos y verdades.” Markapacha: Red Intercultural de Todos los Pueblos. Junio, 2013. Disponível em: < http://www.markapacha.com/blog/?p $=814$ > .

QUEREJAZU, Amaya. “Encountering the Pluriverse: Looking for Alternatives in Other Worlds." Rev. Bras. Polit. Int., 59(2), 2016, p. 1-16.

QUIJANO, Anibal. Colonialidade do poder, eurocentrismo e América Latina. In: Edgardo Lander (org) A colonialidade do saber: eurocentrismo e ciências sociais. Prespectivas latino-americanas. Argentina: CLASCO, 2005.

. “"Bien vivir”: entre el “desarrollo” y la des/colonialidad del poder.” Viento Sur 122 (March 2012), p. 46-56.

QUISPE, Felipe. Interview [April, 2013]. Interviewer: Ana Carolina Teixeira Delgado. La Paz. 1 archive (60min).

REINAGA, Fausto. La Revolución India. El Alto: Imp. “Movil Graf”, 2011.

ROJAS, Cristina. “International Political Economy/Development Otherwise.” Globalizations, December, Vol. 4 (4), 2007, p.573-587. 
. "The place of the social at the World Bank (1949-1981): Mingling race, nation, and knowledge.” Global Social Policy, Vol. 15(1) 2015, p. 23-39.

. "Contesting the Colonial Logics of the International: Toward a Relational Politics for the Pluriverse.” International Political Sociology 10, 2016, p. 369-382.

SANTOS, Boaventura S. "Hablamos del Socialismo del Buen Vivir." América Latina en Movimiento 452, 2010, p. 4-7.

Servicio de Impuestos Nacionales. < http://www.impuestos.gob.bo/index.php?option = com_content\&view $=$ featured\&Itemid $=435>$.

SHAW, Karena. Indigeneity and Political Theory: Sovereignty and the Limits of the Political. London: Routledge, 2008.

SHILLIAM, Robbie. International Relations and Non Western Thought: imperialism, colonialism, and investigations of global modernity. London: Routledge, 2011.

SMITH, Karen. "Contrived boundaries, kinship and ubuntu: a (South) African view of the 'international.” In Arlene Tickner and David Blaney (eds). Thinking the International Differently. London: Routledge, 2012, p. 301-321.

SPEDDING, Alison. “'Suma qamaña’ ¿kamsañ muni? (¿Qué quiere decir 'vivir bien’?).” Fé y Pueblo 17, 2010, p. 4-39.

SVAMPA, Maristela. “Consenso de los Commodities” y lenguajes de valoración en América Latin.” Nueva Sociedad 244, 2013, p.30-46.

STEFANONI, Pablo. “¿Y quién no querría vivir bien? Encrucijadas del proceso de cambio.” Le Monde Diplomatique 200, 2012, p. 23-24.

SMITH, Steve; BOOTH, Ken; ZALEWISKI, Marysia (Eds). International Theory: positivism and beyond. Cambridge: CUP, 1996.

TARROW, Sidney; MCADAM, Doug. “Scale Shift in Transnational Contention.” In: DELLA PORTA, Donatella;TARROW, Sidney (Eds). Transnational Protest and Global Activism. Oxford, UK: Rownan \& Littlefield publishers, 2005, p. 121-147.

THOMPSON, Sinclair. Cuando sólo reinasen los indios. La Paz: La Mirada Salvaje, 2010. TICKNER, Arlene B.; BLANEY, David. "Introduction: thinking difference.” In TICKNER, Arlene B.; BLANEY, David (Eds). Thinking the International Differently. London: Routledge, 2012, p. 1-21.

. Claiming the International. New York: Routledge, 2013.

. "Worlding, Ontological Politics and the Possibility of a Decolonial IR." Millennium, Journal of International Studies 00(0), 2017, p. 1-19.

TICKNER, J. A. Gendering World Politcs. New York: Columbia University Press, 1992.

UNTOJA, Fernando. Retorno al Ayllu. Una Mirada Aymara a la Globalización. La Paz: Ediciones Ayra, 2012.

. Katarismo. Crítica al indianismo e indigenismo. La Paz: Impresión Creativa, 2012a

VÁSQUEZ, Walter. "Redistribución de La riqueza impulsa La economía.” La Razón, 
January 1, 2013. Disponível em: < http://www.la-razon.com/nacional/Redistribucionriqueza-impulsa-economia_0_1766223382.html > .

VIDAL, Hernán. "Retornando a cuestiones indispensables: neoestructuralismo, Estado, cultura nacional.” In: MORAÑA, Mabel (Ed). Cultura y cambio social en América Latina. Madrid: Iberoamericana, 2008, p. 269-280..

VILLANUEVA IMAÑA, Arturo. D. “¿Quo vadis socialismo comunitario para Vivir Bien?” Nueva Crónica y Buen Gobierno 115, 2012, p. 10-11.

VIVEIROS DE CASTRO, Eduardo. “Os Pronomes Cosmológicos e o Perspectivismo Ameríndio.” Mana 2(2), 1996, p. 115-144.

WALSH, Catherine. "Development as Buen Vivir: Institutional arrangements and (de) colonial entanglements”. Development, 53 (1), 2010, p. 15-21.

WALSH, Catherine; GARCÍA LINERA, Álvaro; MIGNOLO, Walter. Interculturalidad, descolonización del estado y del conocimiento. Argentina: Ediciones del Signo, 2006.

WALKER,, Rob. Inside/Outside: International Relations as Political Theory. Cambridge: Cambridge University Press, 1993.

WEAVER, Ole. “The Sociology of a Not so International Discipline: American and European-Developments in International Relations." International Organization 52(4), 1998, p. 687-727.

WENDT, Alexander. Social Theory of International Politics. Cambridge, Cambridge University Press, 1999.

YAMPARA, Simón. El Ayllu y La Territorialidad en Los Andes. Una aproximación a Chambi Grande. El Alto: Ediciones Qamán Pacha CADA, 2001.

- “Comprensión aymara de la tierra-territorio en la cosmovisón andina y su ordenamiento para la/el qamaña.” Revista Inti-Pacha 1-7, 2005, p. 13-44.

YOUATT, Rafi. "Personhood and the Rights of Nature: The New Subjects of Contemporary Earth Politics.” International Political Sociology 11, 2017, p. 39-54. 